\title{
An Exploration of Methods to Improve Process Flow in a Remanufacturing Cell
}

\author{
Terence Bates \\ Postgraduate \\ Waterford Institute of Technology \\ Waterford, Ireland \\ Aidan Walsh \\ Department of Management and Organisation \\ Waterford Institute of Technology \\ Waterford, Ireland
}

(C) Terence Bates and Aidan Walsh. This work is licensed under the Creative Commons Attribution-NonCommercial-ShareAlike 4.0 International License. To view a copy of this license, visit https://creativecommons.org/licenses/by-nc-sa/4.0/ .

\section{Abstract}

This paper examines flow creation within the remanufacturing cell of an Irish medical device manufacturer. The site in question has embarked on a lean journey that commenced in 2003 and has spread site-wide since then. However, despite this progress, achieving balanced work-flow within the remanufacturing cell remains a challenge. The objective of this study is to examine the state of flow within the facility and by understanding this, provide a roadmap for improving flow in the remanufacturing cell. This case study utilises a mixed method approach that includes qualitative interviews, participant observation and evaluation of company documentation and data. Upon initial observation, work-flow within the remanufacturing cell is highly variable mainly driven by the uneven rate of failure of parts returned to the cell; and a lack of visibility as to the rate of demand from production. Following the adoption of practices such as visual management, A3 problem-solving, standard work, kanbans and kitting systems the amount of rework demanded by production cells has reduced by as much as $80 \%$ in some cases. Further improvements were identified in the ability of the remanufacturing cell to effectively service demand. If further gains are to be made then the plant planning system must afford better visibility to the remanufacturing cell. Upon deeper exploration, although the remanufacturing cell presents contextual challenges to balancing flow, an adaption of flow practices can add significant value in designing a robust system of flow within the cell that deeply interacts with the operations of the broader facility as a whole.

Keywords: Remanufacturing; Flow; Lean; Production planning; Visual management

\section{Introduction}

Flow is identified by Bicheno and Holweg (2009) as one of the five core concepts of Lean, and is a prerequisite for efficient processes. Flow is considered a "central principle of lean" (Ball, 2015, p. 415) and indeed the primary focus of lean is to deliver value to the customer by maximising the efficient flow of products and information through processes whilst simultaneously reducing waste (Womack and 
Jones, 2005). This case study examines flow creation within the remanufacturing cell of an Irish-based medical device manufacturer. Despite the fact that the latter has undergone a major lean transformation since 2003, with many lean methodologies and tools embedded across the organisation, work-flow within the remanufacturing cell remains a challenge. This is mainly due to (i) the uneven rate of failure of parts returned to the cell; and (ii) a lack of visibility as to the rate of demand from production. Other factors include inconsistent rates of recovery of parts due to variable amounts of damage incurred during usage in production; and a lack of standardisation. This article begins by providing an overview of remanufacturing and flow. The methodology undertaken for this research is then described. The key results of this study are that although the remanufacturing cell has successfully improved flow through the application of lean principles, restrictions still occur because this operation not yet fully extended the well-established lean systems that are in place in key production areas to the remanufacturing cell, which leads to problems with sustainability.

\section{Theoretical Base}

\section{Remanufacturing}

Remanufacturing is a process whereby components (or sometimes complete units) are collected and returned to a manufacturer or a third party specialising in remanufacturing for reconditioning or re-machining. This extends both the life of the product and its value (Sundin, 2006). The product may also be broken down into smaller components or manufactured into a new component. This process is often employed with items that are of slow obsolescence or are very expensive to produce. Remanufacturing is seen as environmentally friendly as it conserves valuable natural resources and can assist in prolonging the life cycle of a product (Gehin, Zwolinski and Brissaud, 2008). This work can often be highly specialised requiring the skills or inputs of highly experienced tradespeople to bring the component back to being a usable item. Processing times can also fluctuate widely as the condition of the returned items can often vary considerably. Mähl and Östlin (2007) have stated that this factor alone severely impacts on the flow of materials and the planning of a remanufacturing operation. A condition assessment may also be required to ascertain if the product is fit for remanufacture (Sundin, 2006).

\section{Flow}

Liker (2004) states that the goal of every organisation should be the creation of continuous flow in all sides of a business including its service structures. Bicheno and Holweg (2009) state that flow is the central idea in lean and that the primary reason for enabling flow is because flow is directly responsible for delivering value to the customer. Organisations must design their systems in such a way that the outputs of the process are guaranteed and repeatable. This is achieved by generating capacity, controlling the order in which parts are processed, the simplification and error proofing of processes and the design of standards which enable the customer to pull product when it is required. Flow is achieved by the continuous removal of complexity from the process and by focusing on the process rather than the product (Harrison, 1995). 
Achieving flow in a remanufacturing environment is problematic as planning in this type of operation is much more difficult than in a conventional operation (Guide, 1996). The key attributes of this type of system are uneven flow of materials, and undefined processing times, along with the fact that a one size fits all approach does not work. This can make planning to achieve an even flow in this operation difficult (Mähl and Östlin, 2007; Östlin, 2008). In many cases standards as deployed in a conventional manufacturing set-up are not workable as the amount of work required to return a part to usable condition in a remanufacturing scenario is found to be variable. Nevertheless, many of the operations carried out in remanufacturing have commonalities with standard manufacturing processes, and as such lean principles apply (Kucner, 2008). Bottlenecks may shift constantly as parts may not be reworked to the required standard on the first operation. These parts may require further routings through the same machine to become fit for use (Östlin, 2008). This is due to the condition of the returned product, the number of operations required to remanufacture, and the amount of material or parts that are not recoverable (Guide, 1996).

The adoption of the "Flow Framework" (Figure 1) is seen as a strategic action by Bicheno and Holweg (2009, p.34) to ensure that an organisation can steer itself in the right direction. They also state that the framework is a map to enable broad based action rather than just focusing on the tools as this is where organisations often fail in their attempts to become lean. This tool helps an organisation to create flow, keep it going through systemisation and define how flow will be measured. This framework helps an organisation to understand its capacity and how best to exploit this in the marketplace.

Figure 1: The Flow Framework

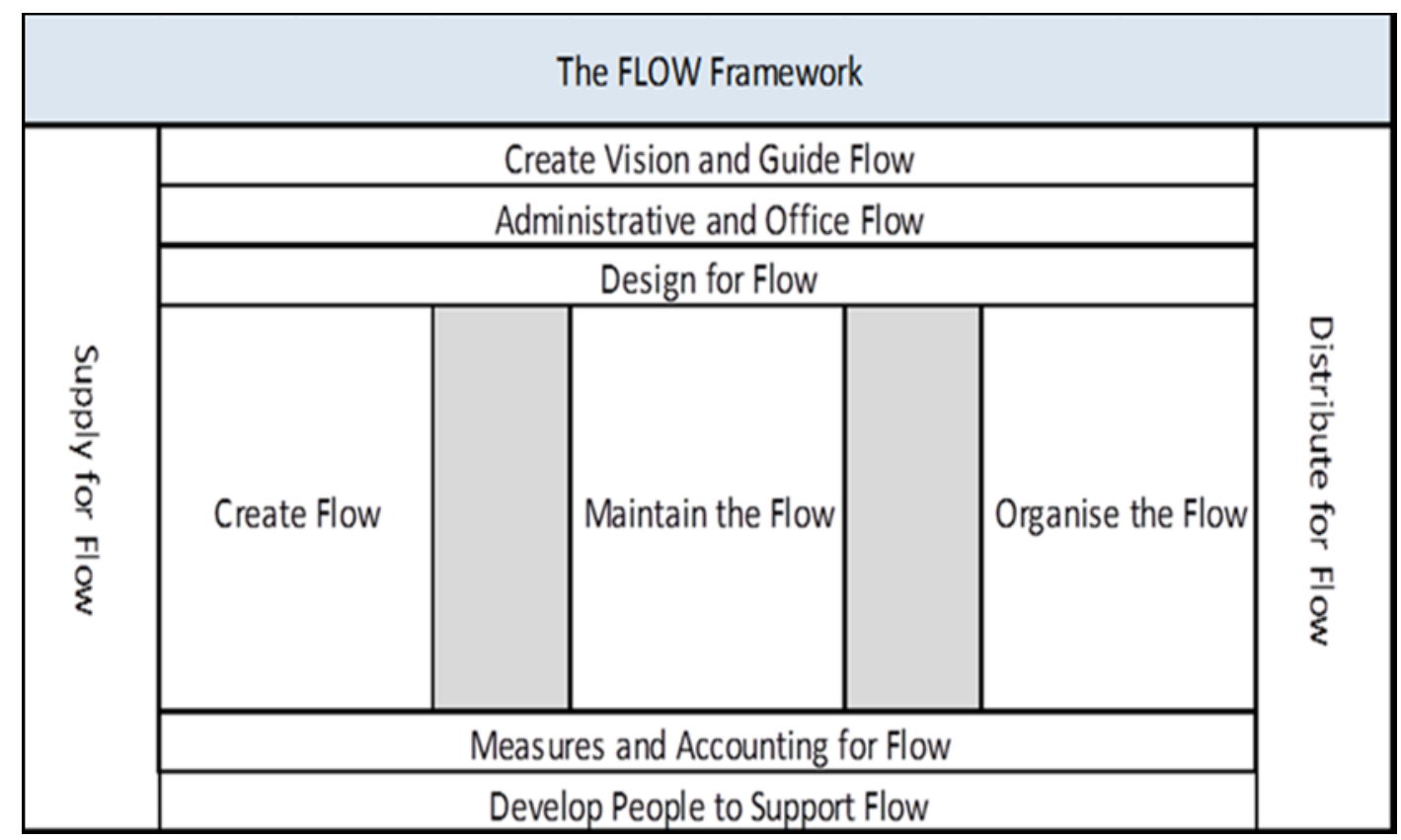

Source: Bicheno and Holweg (2009, p.34). 
Lean principles can be applied in a remanufacturing scenario helping to increase productivity, reduce costs, improve quality and empower employees (Hunter and Black, 2007; Östlin, 2008; Kucner, 2008). Companies make use of a diverse range of planning and control options to smooth the flow of parts through the system and control inventory. Customised MRP systems, the deployment of kanbans, Theory of Constraints and economic order quantities are some of the tools used (Guide, 2000). When dealing with contingencies an operation must look at the external environment it services, decide its core process and then apply the most suitable contingency theory construct to achieve the best fit (Kucner, 2008).

Kucner (2008) also found that the deployment of visual management techniques were advantageous in promoting flow in the remanufacturing system. These techniques provided the following benefits in the areas studied: empowerment of employees, accurate analysis of production at any point in time and improved communication throughout the facilities.

One way of dealing with the unevenness in remanufacturing and help to promote flow is to increase the buffers between the processes (Sundin, 2006). The use of Constant Work in Process (CONWIP) originally developed by Spearman, Woodruff and Hopp (1990) offers the benefits of Kanban systems in varying production environments. Finite capacity scheduling is also seen by Irani (2011) as advantageous. Efficient scheduling of operations generates a smooth flow of inventory through the system but flow is extremely difficult to achieve if your demand is uneven (Nicholas, 1998).

Originating in Toyota, the purpose of heijunka is to smooth the demand on the production line by aligning the process times, in so far as is reasonably possible, to the one time $(O h n o, 1988)$. It is now a cornerstone of the lean manufacturing system. The levelling of production is achieved by the use of in-process buffer stocks or uniform production schedules where the same amount of parts are produced at timed intervals (Nicholas, 1998). The applicability of heijunka in remanufacturing is questionable with Irani (2011) stating that it does not always work in a highly variable situation. Kucner (2008) found that the system had been used successfully in a shipyard but it led to workers being pulled off active jobs and on to other tasks.

Value stream mapping (VSM) is a technique that can assist organisations with the visualisation, analysis and redesign of processes (Rother and Shook, 1998; Womack and Jones, 2002; Matt, 2008). Value stream maps are useful as they not only illustrate material flows but also illustrate information flows that support processes. Value stream maps provide an effective means for providing a strategic direction for where opportunity for improvement might occur (Martin and Osterling, 2004). The case study organisation has begun utilising value stream mapping on selected areas but this is at a very early stage and has yet to implement VSM activity sitewide. For that reason the authors did not investigate VSM activity at the site, but recommend that VSM activity be expanded and extended to all site operations.

First introduced by Goldratt and Cox in "The Goal" (1984), Theory of Constraints (TOC) has come to be seen by authors such as Irani (2011) as being superior and a 
better strategic fit for job shop and remanufacturing operations when compared to "Six Sigma" or a traditional lean approach. This system advocates the employment of a "drum-buffer-rope" system based around the most constrained resource in the system. This designs production promoting "continuous flow" to ensure the bottleneck process is continuously fed, balancing the flow of work through the system but not balancing the capacity (Harrison, 1995). If continuous flow is to be enabled it is, however, vital to have as much visibility as possible between the organisation and its customers to ensure the right parts are produced with minimal disruption to the system (Irani, 2011; Bicheno and Holweg, 2009; Schragenheim, Dettmer and Patterson, 2009; Harrison, 1995).

Bicheno and Holweg (2009) state that kanban systems are deployed in a number of production scenarios. These may consist of card based control systems which authorise the stocking of a part or signalling the production of a part to commence. Harrison (1995) states that kanbans are more associated with push systems and must be properly controlled if they are to promote flow. Another drawback that may occur in the use of kanban systems is that they can dramatically increase the level of inventory in a system (Harrod and Kanet, 2013). Also if there are large amount of product families to be catered for the cost of maintaining these kanbans may be prohibitive (Harrison, 1995); Harrod and Kanet (2013, p. 621) also state that one of the main deficiencies of operating a kanban system is that the system often fails due to the fact that competing jobs are not prioritised, leading to a queue at a work centre. Caputo and Pelagagge (2011) advocate kitting operations as being a better strategic fit to feed assembly operations. They state that the issues normally seen with kanban operations are not associated with kitting as this system ensures only the correct amount of parts required to build an order are present on the line at one time. This coupled with the fact that the visibility afforded through planning this type of operation is seen as the least wasteful of resources.

Kattman et al. (2012) state that visual management helps to drive waste from the work system. This permits the flow of information and enables rapid decisionmaking. The transparency afforded by visual management eliminates the need to look for information, tools or material as all are in place where employees need them, therefore empowering employees (Kattman et al., 2012). This eliminates the tendency people have to store information internally as the information required to make decisions is always at hand (Tezel, Koskela and Tzortzopoulos, 2009). Sundin (2006) conducted a case study into seven companies involved in remanufacturing. It was found that where the use of visual management was below average, the flow of product through the system along with the control of inventory and W.I.P. was negatively affected. This resulted in large amounts of capital being tied up in the system.

A key element of standard work is TWI (Training within Industry) which is reported by Bicheno and Holweg (2016, p.146) to be "arguably the most effective and influential training programme ever developed". Labach (2010) describes standard work as a series of tasks which are designed to be completed to the TAKT time (rate of customer demand) which achieves a levelling of production in a manufacturing system. This is achieved by defining "the one best way" of completing a task. This enables standard times and work sequences to be set for the completion of the 
different tasks. Standard work aids in the reduction of defects, reduces work in process, cuts costs and aids in the achieving of consistent outputs (Labach, 2010).

The deployment of standard work in a remanufacturing system is seen as essential to achieving consistent operations (Hunter and Black, 2007). The formulation of these instructions which are both highly detailed and precise, relating directly to the original product drawings, has been found to be advantageous (Kucner, 2008). Dixon (2009) advocates the development and use of standard work for repetitive tasks in a job shop to help remove waste and improve responsiveness. This along with error-proofing (poke-yoke) devices helps to build quality in at every step and promote flow throughout the process. The role of the supervisor in a remanufacturing scenario is markedly different to that of a job shop. In this situation the supervisor's primary task lies in developing standard work for the repeat jobs that exist in the facility (Hunter and Black, 2007).

Many operations involved in remanufacturing have tried to use traditional planning approaches but these have been left wanting as the planning requirements of a remanufacturing operation are unique (Guide, Jayaraman and Linton, 2003). As a result of this, organisations attempting to use a one size fits all approach to planning and scheduling of work in a remanufacturing context were highly likely to fail. When adopting a contingency approach to a remanufacturing operation it is essential that the planners build the operation to suit the rate of arrival of returned product and the type of remanufacturing operation that is to take place, i.e. remanufacture to order, reassemble to order or remanufacture to stock (Guide, Jayaraman and Linton, 2003).

When these constraints are considered it is of vital importance that the remanufacturing operation gains as much visibility as possible on up-stream operations to help to smooth the flow (Sundin, 2006). Traditional lean approaches often do not work in environments where unevenness in both demand and time to process constrain the planning outputs (Irani, 2011). The use of flow control systems such as Kanban and CONWIP to promote flow in a make to order system must also be approached with caution as the levels of WIP in the system may increase, negatively affecting the cash balance (Harrod and Kanet, 2013).

If flow can be successfully implemented it can provide many benefits to a remanufacturing operation. The empowerment of employees and the building-in of quality at every step form the basis for a fast, flexible system which enables a rapid response to customer demand (Östlin, 2008). The end result is a robust and costeffective system where inventory levels and scrap or unplanned work are reduced. Environmental impact is also reduced and the business strengthened for the future (Östlin, 2008).

It is generally accepted that lean methodologies do have a place in remanufacturing. However the tools as originally designed will not always work in a remanufacturing system but through modification they can be applicable (Irani, 2011). It is essential that an organisation gains as much visibility as possible from its customers and from there proceeds to finite scheduling to aid in the rapid execution of orders (Irani, 2011). The deployment of standard work, as described by Hunter and Black (2007), 
visual management, as surveyed by Sundin (2006) and TOC (Guide, 1996) have their place in promoting flow in a remanufacturing system.

\section{Methodology}

A case study approach that incorporated the use of mixed methods was utilised in this study. Yin (2003) states that case studies are particularly suitable for the investigation of real-world phenomena. A review of the literature indicated a lack of research that studied flow in a remanufacturing environment. The research design utilised three forms of data from the organisation.

As the question asked in this case was complex, the availability of data had a major bearing on the research design. Process performance data from the site operations was accessed to obtain a picture of the operating systems in the organisation. The organisation that is the subject of this case has an array of secondary data permitting an in-depth analysis contributing to the understanding of this case. The data included standard operating procedures and various records relating to the use of remanufactured product. This data was chosen as it offered many advantages, including permitting the analysis of data gathered over an extended time frame (Saunders, Lewis and Thornhill, 2003; Cowton, 1998). The advantages of using secondary data are that it has already been collected, it saves research time, is costefficient and the volume of data that is available can be greater than researchers could collect themselves. The disadvantages of secondary data are that it may have been collected for a purpose other than the researcher's, it may be inaccurate or it may not accurately reflect current conditions.

Participant observation is especially useful in case study applications as it can provide an extensive and in-depth analysis of a problem and is less intrusive than conventional inquiry (Jorgensen, 1989). The observation was carried out by the author during the months of April and May 2014. Participant observation was utilised to understand the human element relating to the problem. Observations were taken on efficiencies of respective processes, downtime reasons, incidence of quality spills, action card raised and the reporting systems in place in each area. Morning meetings were attended in six operations areas on various weekdays during May 2014 and observations were recorded. Participant observation was utilised as it added current context and current data to the secondary data already gathered. It also provided the researcher the opportunity to observe systems in practice and record any divergence between standard operating practices and actual practice.

The data from secondary sources and participant observation were used to inform the questioning for the qualitative interviews. The author then adopted a semistructured approach to the interviews. DiCicco-Bloom and Crabtree (2006) stated that a semi-structured approach to interviews affords an opportunity to enrich the research through the insights of the interviewees. The researchers conducted qualitative interviews to gather richer data about the behaviours underpinning the practices and systems utilised in the system and to understand participants' opinions on the performance of practices designed to improve flow. 
The interviews and the participant observation for this case study were analysed using NVivo software. For the purpose of the study the author chose to analyse the qualitative data using a thematic approach as outlined by Creswell (2007). Other approaches were considered but the thematic approach has been deemed to be most suited in this case. The literature review focused on three pillars to achieving flow in a lean system (planning, standard work and visual management) and as such the author chose to construct a line of questioning based on these pillars.

The sample for these interviews came from the supervisory team, the planning group and from the remanufacturing cell. A total of five supervisors, one planner and one remanufacturing cell employee were interviewed. Table 1 below illustrates the role, length of service, breadth of knowledge and time spent in current role for each interviewee.

Table 1: Breakdown of interview participants

\begin{tabular}{|l|c|c|l|c|}
\hline Employee & $\begin{array}{l}\text { Years of } \\
\text { service. }\end{array}$ & $\begin{array}{l}\text { No. of areas } \\
\text { employed in. }\end{array}$ & Current role. & $\begin{array}{l}\text { Time employed in } \\
\text { current role. }\end{array}$ \\
\hline Employee 1 & 10 & 1 & Supervisor & 10 years \\
\hline Employee 2 & 11 & 1 & Supervisor & 6 years \\
\hline Employee 3 & 15 & 2 & Supervisor & 7 years \\
\hline Employee 4 & 13 & 2 & Supervisor & 4 years \\
\hline Employee 5 & 10 & 4 & Supervisor & 2 months \\
\hline Employee 6 & 19 & 7 & Planner & 3 years \\
\hline Employee 7 & 4 & 4 & $\begin{array}{l}\text { Production } \\
\text { Support } \\
\text { Employee }\end{array}$ & 9 months \\
\hline
\end{tabular}

The supervisors are responsible for the different stages of product manufacture and also have the unusual distinction of being both a customer as well as a supplier. The planner is responsible for planning the orders for each department apart from the remanufacturing cell. The employee from the remanufacturing cell is responsible for the supply of consumable items to the production areas. The insight of each respective value stream into daily requirements was vital if a rounded picture of the organisation was to be gained.

To summarise, the case research was performed by using the following sources of information during the research project:

- Secondary information concerning process performance, standard operating procedures, quality data and $A 3$ reports.

- Direct observation at daily performance management meetings to observe participant behaviour and activity.

- Qualitative interviews with employees who have direct input into the site operations and remanufacturing operations. 
By obtaining data from three different sources the researchers were able to triangulate their findings. This assisted in confirming observation drawn from the analysis of one source of data. There are limitations to this research. Firstly, only one case study organisation was chosen and the findings may not be representative of other firms. Secondly, although a significant amount of data was obtained by three different methods, time and monetary constraints limited the period of observation and the sample size.

\section{Research Hypotheses}

Bicheno and Holweg's (2009) "Flow Framework" was adopted as a roadmap to promote flow in both the remanufacturing operation and the wider organisation. Four hypotheses were developed to examine this phenomenon, namely:

Hypothesis 1: That visual management systems have a role in supporting flow within the facility.

Hypothesis 2: That the introduction of standard work will support flow within the remanufacturing cell.

Hypothesis 3: That the existing planning structures take little consideration of the remanufacturing cell.

Hypothesis 4: That demand variability within the cell can be managed by the introduction of an appropriate system.

\section{Findings}

The ultimate goal of this project was to introduce a system to better manage the flow of work in the remanufacturing cell while still maintaining production requirements. The key constraining factors present in the remanufacturing cell are variability in the time taken to remanufacture consumables, coupled with the amount of visibility the cell has in relation to production demands. It is important to note that several 'Lean Tools' have been implemented by the team within the remanufacturing cell to support flow. Chief among these are visual management, kanbans, A3 problemsolving and standard work. An analysis of these changes is conducted, along with an exploration of planning systems within the facility, and how this affects flow in the remanufacturing cell.

The findings of this study are constructed by triangulation of the three types of data used to compile an accurate picture of operations within the facility; namely the use of secondary data, participant observation and qualitative interviews. The literature noted the complexity of remanufacturing operations and the unique constraints that must be addressed if "flow" is to be enabled and maintained.

The opinions of the interviewees will be distinguished by using a different code for each interviewee as illustrated in Table 2 below: 
Table 2: Referencing system deployed for illustrating the responses of each interviewee

\begin{tabular}{|c|c|}
\hline Interviewee & Reference \\
\hline Employee 1 & E1 \\
\hline Employee 2 & E2 \\
\hline Employee 3 & E3 \\
\hline Employee 4 & E4 \\
\hline Employee 5 & E5 \\
\hline Employee 6 & E6 \\
\hline Employee 7 & E7 \\
\hline
\end{tabular}

Scrutiny of $\mathrm{H1}$ : That visual management systems have a role in supporting flow within the facility

Kanbans of consumables are widely used across the plant including in the remanufacturing cell. All of the people interviewed agreed that the kanbans are meeting the levels of requirement with instances of stockout being rare. These kanbans are used to hold consumable items which support the manufacturing operation.

Figure 2: Assembly Crash Cart Filled with Consumables

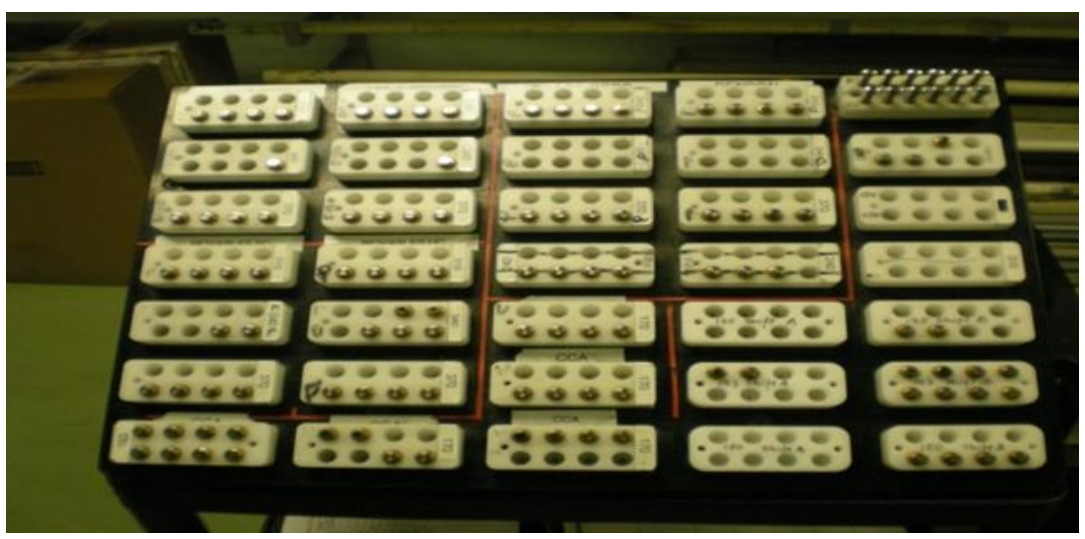

Crash carts, as shown in Figure 2, are deployed by the remanufacturing cell when conducting milk-runs on each shift to restock the shadow board kanbans on the respective assembly lines. The deployment of these carts and the milk-run system has proven highly effective in supporting the manufacturing operation.

Table 3 illustrates the opinion of the interview participants on the use of kanbans within in the facility. Interviewees were asked if the use of kanbans positively impact 
on flow in the operations. All indicated positive outcomes from the use of kanbans; however interviewees E6 and E7 drew attention to the fact that the system had to be used correctly and consistently to avoid slippage in performance.

\section{Table 3: Opinions on whether the use of kanbans within the facility had a positive impact}

\begin{tabular}{|c|c|}
\hline Interviewee & Response \\
\hline El & $\begin{array}{l}\text { "Yes the kanban system has a mark, but I also know that the Toolroom has a level of } \\
\text { clean pulleys to replenish quickly if we get to that level so there's a level in place } \\
\text { within the area and within the toolroom to prevent stockouts". }\end{array}$ \\
\hline E2 & $\begin{array}{l}\text { "The visual management systems on our kanbans.....as I say we don't have an awful } \\
\text { lot of issues with the kanban and supply of consumables so I think what we have in } \\
\text { place is working well". }\end{array}$ \\
\hline E3 & "Yes they are and they are updated every week". \\
\hline E4 & $\begin{array}{l}\text { "They certainly do that's the whole point of them I suppose back many years ago it } \\
\text { wouldn't be unusual to have a stockout ....we have been supplied with the appropriate } \\
\text { collets from the Toolroom but maybe we have gone through them too soon, changed } \\
\text { them too soon without really identifying the real cause of our problems". }\end{array}$ \\
\hline E5 & $\begin{array}{l}\text { "Yes, yes as long as they are kept we do regular checks, teamleads check them, } \\
\text { supervisors check them to make sure that what's required on them is kept on them. } \\
\text {...this kind of keeps them up to date and everything the operators need are there for } \\
\text { them". }\end{array}$ \\
\hline E6 & $\begin{array}{l}\text { "They do I mean no body is perfect so because we might have and I remember there } \\
\text { was a situation where we had some shifts on weekend work and we don't have others } \\
\text {....like the warehouse don't work Saturday." }\end{array}$ \\
\hline E7 & $\begin{array}{l}\text { "For us I think we're ok on them ones we usually have what we need unless people } \\
\text { are coming up for something different without giving us notice and then we will run } \\
\text { out". }\end{array}$ \\
\hline
\end{tabular}

Kitting systems are deployed for the high volume, low variety cells and the night shift. This permits an exact list of consumables to be delivered at the end of shift so the line is left fully kitted. This system currently works well but there are instances where lack of visibility negatively effects the kitting operation in the remanufacturing cell, prompting $\mathrm{E} 7$ to comment in his interview that:

"for one of the lines "Odds and Sods" we'd get a box at the end of the shift from them in the last couple of hours of the shift. Sometimes that's done and it's changed without any notice. They come up to us at 6 o'clock in the morning maybe looking for different collets and we don't have them" [E7] 
This may be due to the fact that the line leads are not given visibility on what is "coming down the track" as the supply of required components is not finite scheduled [E4]. Morning meeting boards as shown in Figure 3 and "hour by hour" boards as shown in Figure 4 are also deployed in the production areas. These boards are used to visualise where a shift is in relation to its planned workload. During the morning meetings efficiencies are reported and if there is a problem or an improvement action required, an action card is placed on the board. The cards are discussed by the cross-functional team members who attend the meeting.

Figure 3: Morning Meeting Board containing Action Cards

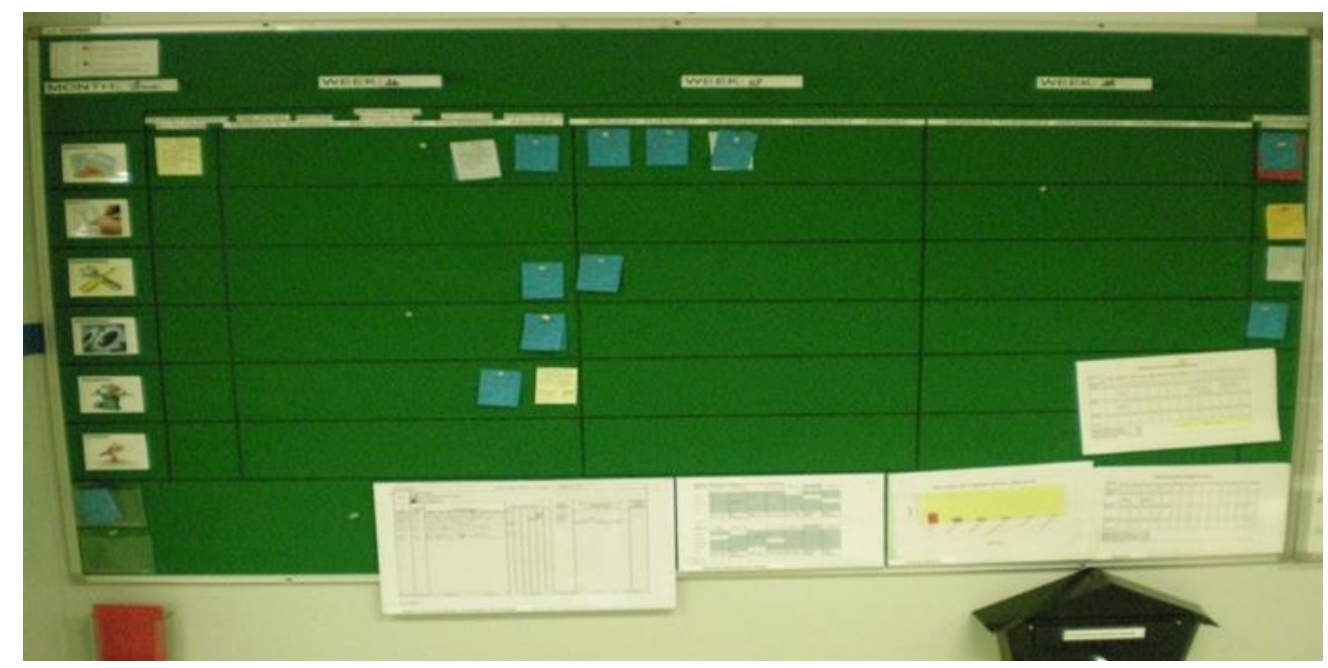

Figure 4: Hour by Hour Board from the Facility

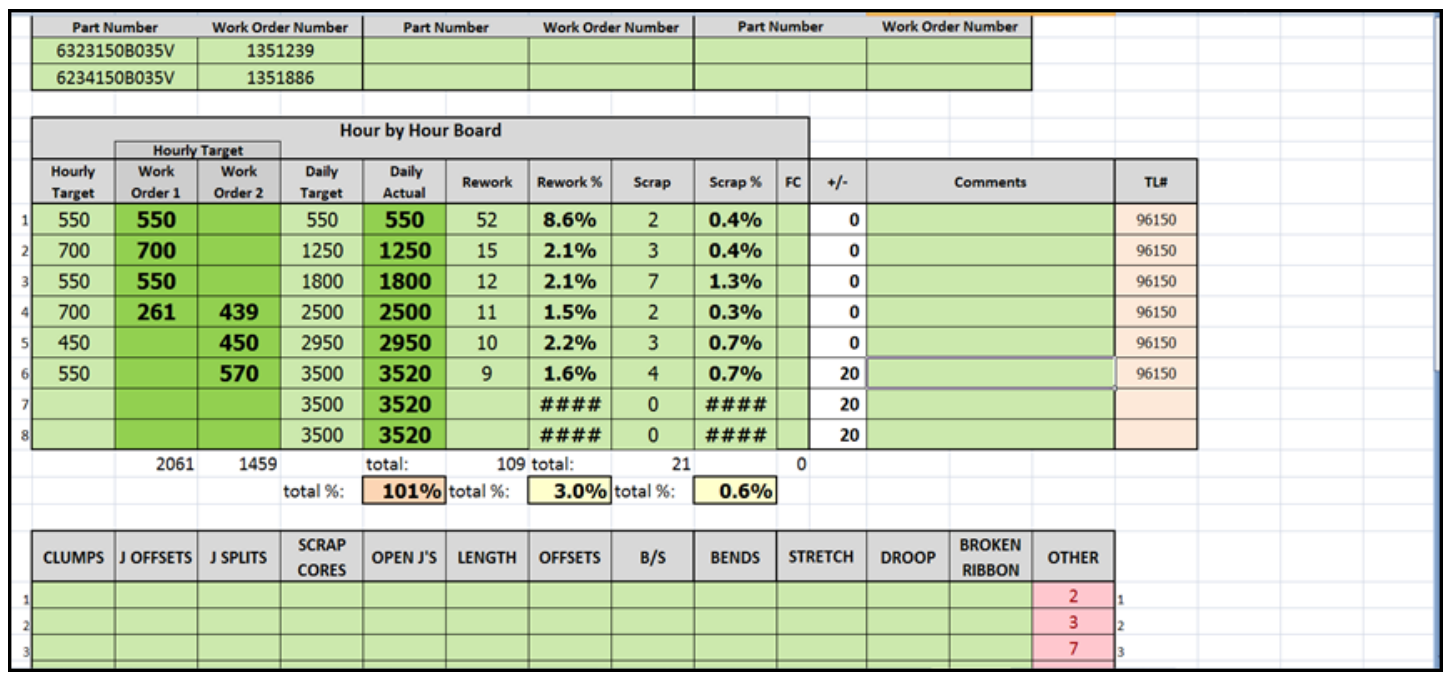


The introduction of visual management boards has made it easier to control and track process performance and thus visualise process flow. This allows for earlier identification of process problems and has minimised disruption to flow.

\section{Scrutiny of H2: That the introduction of standard work will support flow within the remanufacturing cell}

Based on its success in other areas of the plant the management team was of the opinion that standard work would play a crucial role in this new system. An observation by the remanufacturing team is a definite requirement to tightly specify the original parts at their point of manufacture in an effort to make reprocessing easier. To this end, A3 problem-solving has been deployed to all areas to minimise variation and promote standardisation. Figure 5 details just one of several A3 problem-solving projects that have taken place which have reduced variability in the remanufacturing operation. The results of these projects have then helped to introduce the standard work within the area. One of the major constraining factors relating to remanufacturing is the fact that the amount of work required to bring a part back to usable condition is highly variable due to an uncertain level of wear. A3 problem-solving and standard work have helped to build in capacity in the remanufacturing operation as there is now less variability in the quality of returned parts.

Figure 5: $A 3$ to reduce collet usage

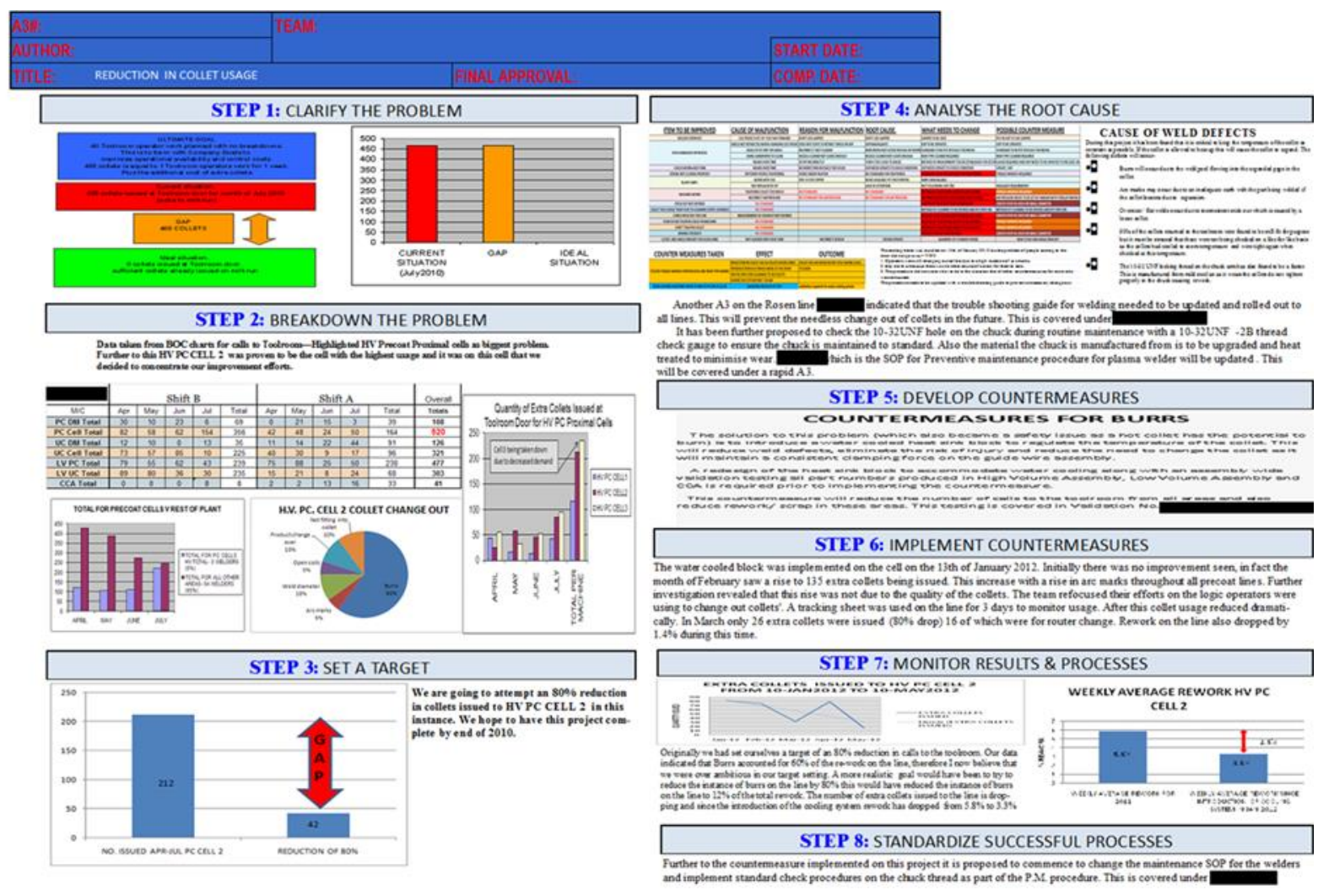


Figure 5 illustrates an A3 problem-solving exercise that sought a reduction in calls to the remanufacturing specifically in rework on collets used in key operations areas. By introducing a cooling system on the line in a production cell it was possible to achieve a reduction of rework to this line from $5.8 \%$ to $3.3 \%$.

Figures 6 and 7 detail the results of the implementation of standardisation on the quantity of consumables required by some of the manufacturing areas thus helping the flow of work not just in the remanufacturing cell but in the manufacturing area it supports. Monetary savings accrued from these projects but this data was confidential and cannot be disclosed.

Figure 6: Reduction in collet usage

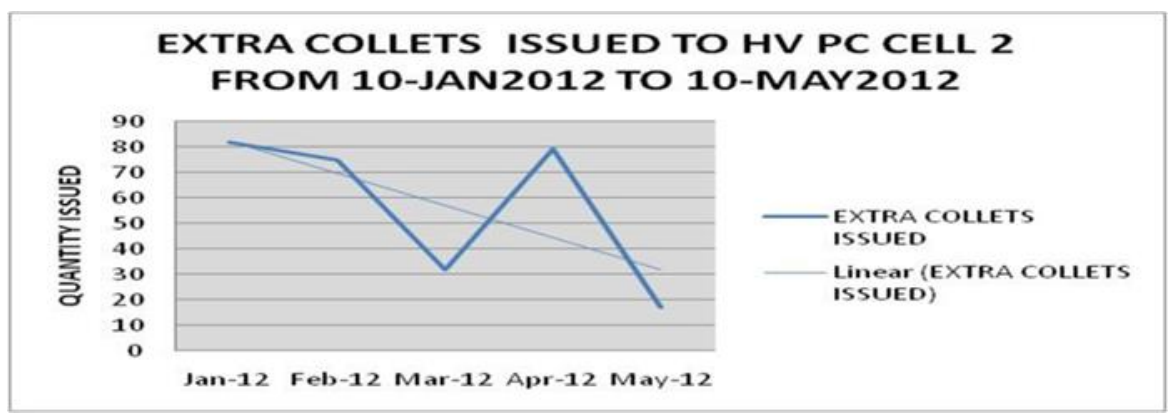

Figure 6 illustrates a reduction in the number of collets issued to HV PC Cell 2 by the remanufacturing cell from 81 in January to 18 in May 2012.

Figure 7: Reduction in snips usage

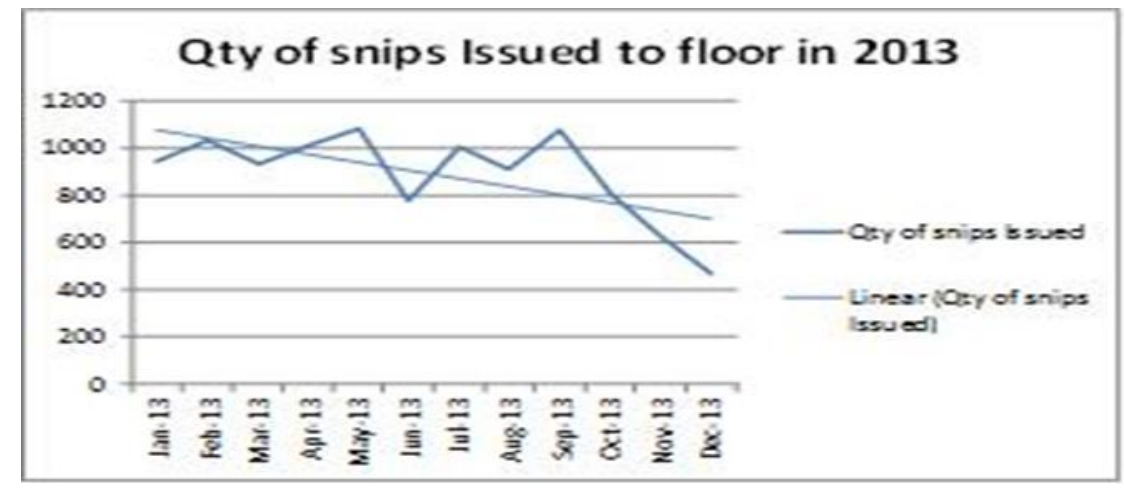

Similarly Figure 7 illustrated a $50 \%$ decline in the quantity of snips issued by the remanufacturing cell to the production floor from approximately 1,000 snips in JanFeb 2013 to less than 500 in December 2013.

E4 in particular made reference to these projects stating: 
"There's been a huge improvement I would see in the service levels coming from the Toolroom" [E4]

The goal of these projects from the outset was to move to a situation where reprocessing times could be standardised at their most efficient. A drive was made to adopt "the one best way" of reprocessing the consumables to ensure efficient operations. This is leading to the adoption and implementation of clearly defined work instructions which in turn are bolstered by the use of "Job Breakdown Sheets" (see Figure 8 below).

Figure 8: A Job Breakdown Sheet from the Remanufacturing Cell

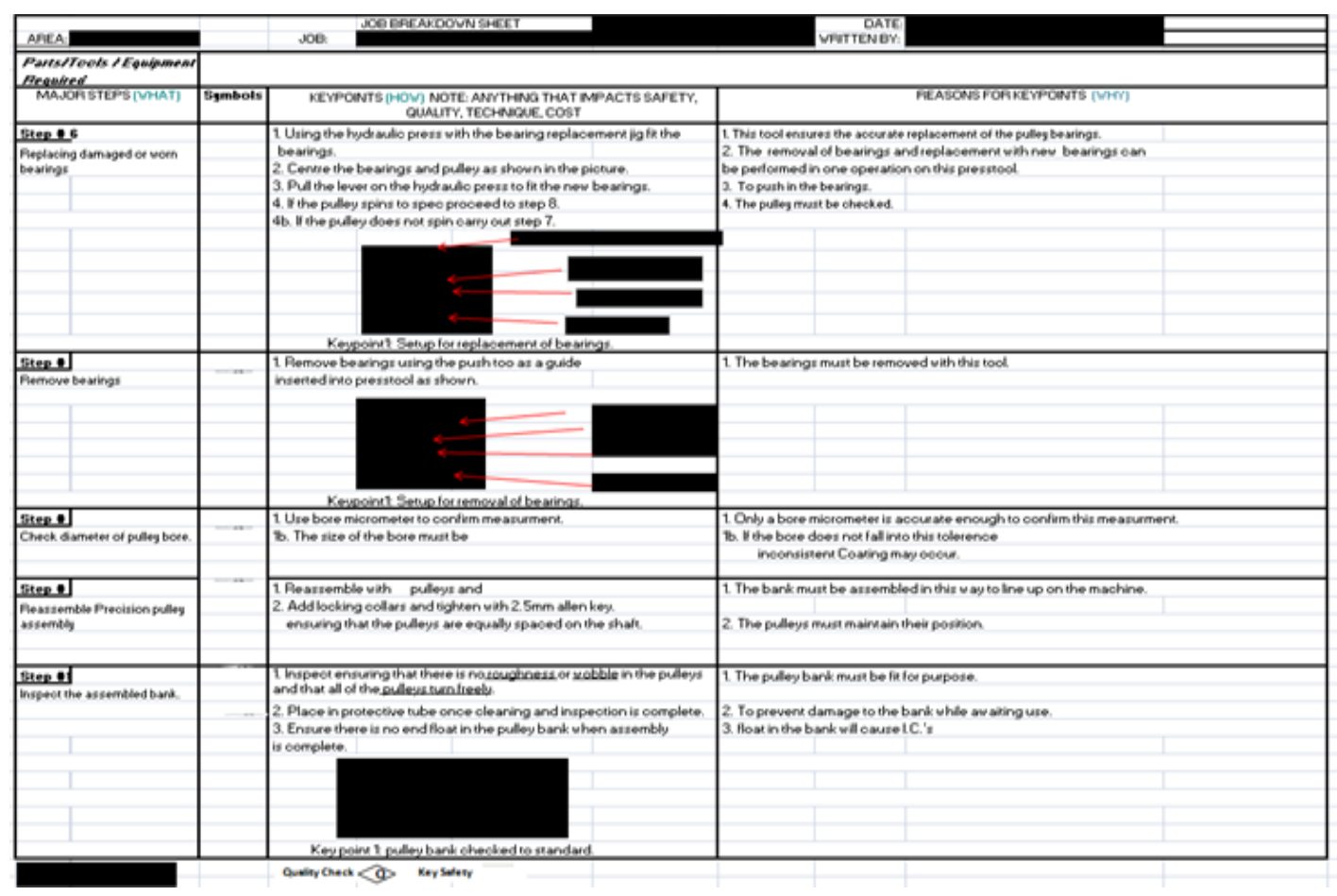

This approach has increased the skill level amongst the members of the remanufacturing cell along with demonstrating a high degree of standardisation in the abilities of the team.

\section{Scrutiny of H3: That the existing planning structures take little consideration of the remanufacturing cell}

An analysis of the interviews revealed that to date the planning procedures in the facility do not, to any great extent, factor in the remanufacturing cell or its capacity to meet demand. E7 stated that:

"if we had a better idea of what was running we could have stuff ready there instead of people just coming up, I want this collet, I want more snips, I want more stuff that we don't [have] ready for them" [ E7]. 
Indeed the only area where planning have any visibility over remanufacturing operations is as E6 stated:

"the one that we do is if there is overtime because if it goes outside the standard work and there is overtime at the weekend and it exceeds a couple of lines... we know it is going to effect the supply of consumables" [ E6].

Day to day operations are governed by kanbans and kitting to simplify supporting the production areas as E5 stated:

"for the rest of the cells making more standard work we would have a visual system whereby a daily milk-run by the Toolroom and they would also replenish the shadow board with collets" [E5]

The current structure of planning in the facility is comprised of weekly buckets, the bucket being the term used to describe the quantity of work orders due for manufacture in that week. In this system all of the orders for that week fall due on the same day. When asked if this system supported work flow in their respective areas the responses were mixed and varied from the respondents. In areas where it is difficult to plan it was felt that they did not afford enough visibility to downstream activities. It also emerged that the "siloed structures" between departments appeared to be creating an obstacle where a lack of harmonisation in relation to order priority and visibility was currently negatively affecting flow.

The existing planning structures at the plant have not fully extended to the remanufacturing cell and the resulting lack of visibility is restricting the ability of the remanufacturing cell to service the production area demand in a consistently effective manner.

\section{Scrutiny of H4: Demand variability in the remanufacturing cell can be managed by the introduction of the appropriate system}

One of the major constraining factors relating to remanufacturing is the fact that the amount of work required to bring a part back to usable condition is highly variable due to an uncertain level of wear. Figure 9 below, taken from a time study conducted in 2013 , clearly shows the variability in remanufacturing times for one of the product families the cell produces. 
Figure 9: Time Study Data for Remanufacture of one Product Family

\begin{tabular}{|c|c|c|c|c|c|c|}
\hline Date & Time & $\begin{array}{c}\text { Collet } \\
\text { Type }\end{array}$ & \#Collets & $\begin{array}{c}\text { Time } \\
\text { taken/Secs }\end{array}$ & $\begin{array}{c}\text { Time taken per } \\
\text { collet/Secs }\end{array}$ & Comments \\
\hline $28 / 02 / 2013$ & 12.00 & 340 & 5 & 618 & 123.60 & Interrupted 2 mins - collets needed for Benson Line \\
\hline $28 / 02 / 2013$ & 14.10 & Module & 10 & 1935 & 193.50 & Fiddly - 3 needed reworking \\
\hline $28 / 02 / 2013$ & 14.43 & 170 & 10 & 2285 & 228.50 & \\
\hline $01 / 03 / 2013$ & 14.21 & 170 & 6 & 1384 & 230.67 & \\
\hline $04 / 03 / 2013$ & 14.10 & $\begin{array}{c}\text { Precoat } \\
340\end{array}$ & 21 & 2587 & 123.19 & \\
\hline $04 / 03 / 2013$ & 15.09 & $\begin{array}{c}\text { Uncoat } \\
340\end{array}$ & 17 & 2409 & 141.71 & \\
\hline $05 / 03 / 2013$ & 14.32 & Module & 10 & 2120 & 212.00 & Interrupted 43 secs- collets needed for PM02 and Precoat Cell2 \\
\hline $06 / 03 / 2013$ & 14.10 & 135 & 6 & 1980 & 330.00 & \\
\hline $07 / 03 / 2013$ & 14.18 & 170 & 4 & 2196 & 549.00 & 3 out of the 4 were scrapped and had to be made from scratch \\
\hline $07 / 03 / 2013$ & 14.21 & 240 & 6 & 1935 & 322.50 & \\
\hline & & & & & & \\
\hline
\end{tabular}

Whilst A3 problem-solving and standard work have been deployed to reduce variation in the actual remanufacture of the consumables, an analysis of the secondary data conducted during the study showed there is still some tightening of standards required in the manufacturing operation, particularly in relation to planning, to better regulate the flow of returns to the cell. In May 2014 (refer to Figure 10), during the time of the participant observation, over 900 extra parts of one consumable family were issued to the assembly floor. This corresponds to nine days of extra work for one operator. This was unplanned demand. This variability in demand currently necessitates that the cell carries extra headcount when compared to a normal manufacturing operation to enable it to cope with the surges in demand.

Figure 10: Uneven Flow back into the Cell for May 2014

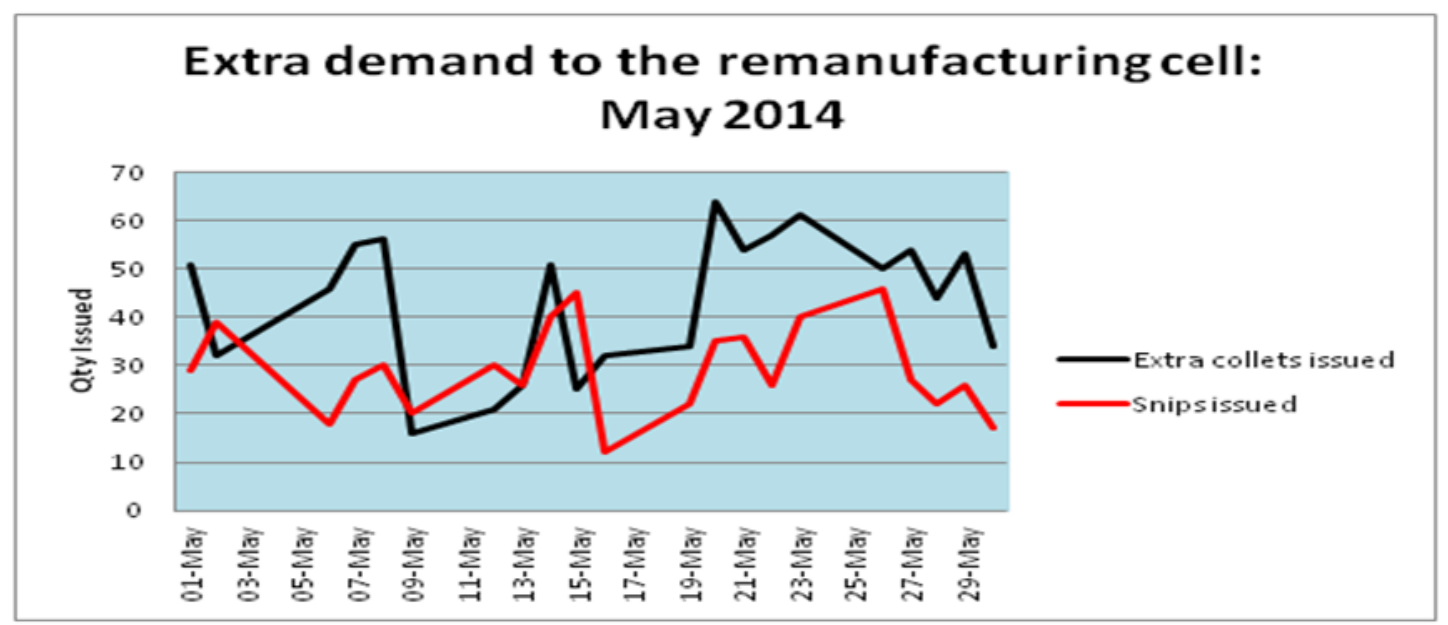


These consumables were issued even though only five instances were observed during the study where extra consumables were requested for cells that were not meeting efficiency. This totalled 18 parts from the remanufacturing cell. Also in these instances supplementing the cell allotment with these extras only had a positive impact in three of the five cases.

In $76 \%$ of instances where the cells were behind target at the morning meeting (three hours into the shift), three-quarters of these lines had managed to make this deficit back by shift end according to study of the corresponding shift reports. This clearly points to a high degree of elasticity within the current process which can in turn cause spikes in demand to the remanufacturing cell.

This was apparent when both the secondary data and participant observation were analysed. This clearly points to a need to tighten some of the standards in the operation to better regulate the flow of returns to the cell. The elasticity in the manufacturing operation is causing peaks and troughs in the rate of parts being returned to the cell. Currently breakdown occurrence charts (BOC) are deployed in the remanufacturing cell to track the usage on extra consumables issued during the shift. These charts track consumable usage and indicates where surges in use are taking place (refer to Figure 11). While this approach is used in the facility, the author did not see a set trigger point for escalation to prompt the remanufacturing cell to intervene.

Figure 11: Example of a Breakdown Occurrence Chart

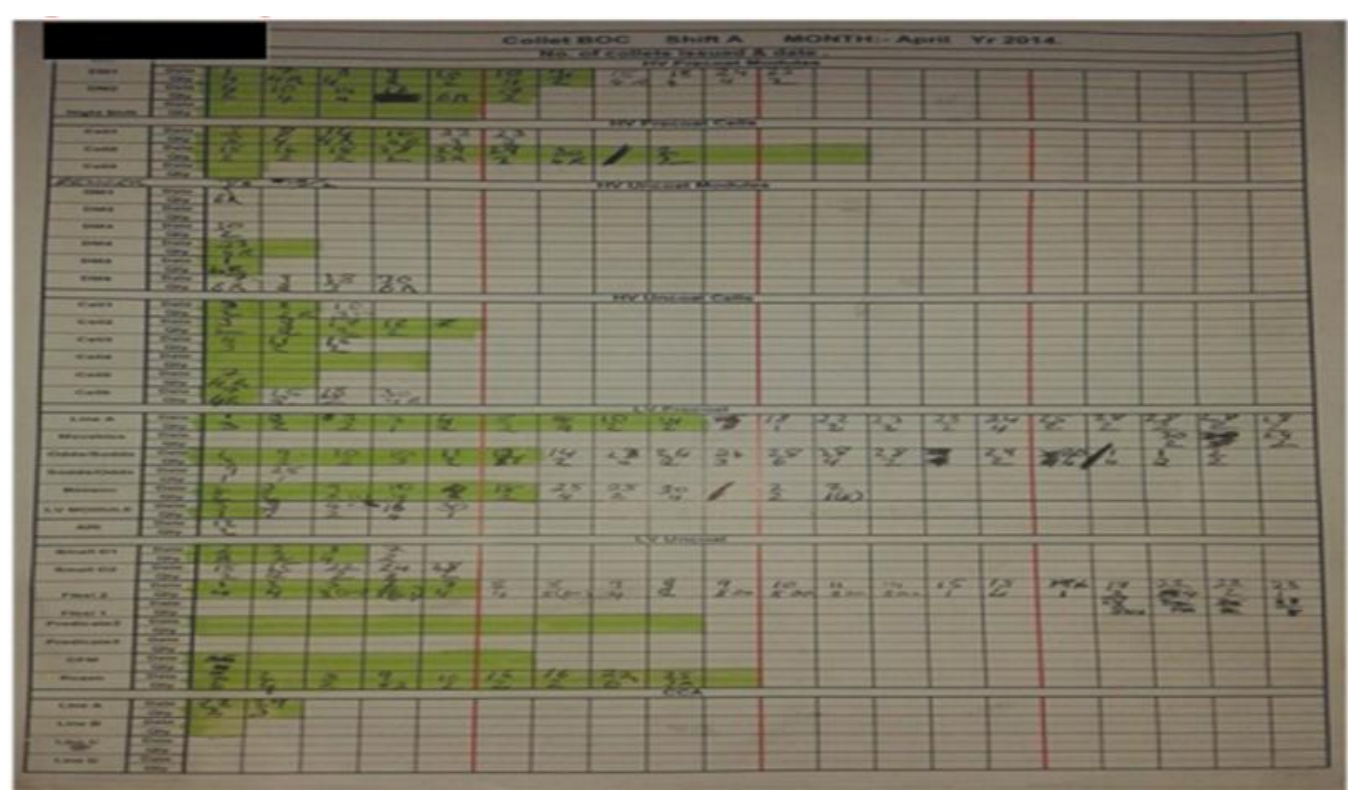




\section{Summary of Key Findings}

\section{Scrutiny of $\mathrm{H} 1$ : That visual management systems have a role in supporting flow within the facility}

The visual management systems currently deployed are of a high standard. The use of kanbans with clearly defined replenishment points being a notable positive. In line with the findings of previous authors such as Kucner (2008) and Sundin (2006), this system is supporting flow in the facility. The entire management stream interviewed clearly stated that the occurrence of stockouts is rare. The use of crash carts in the remanufacturing cell has certainly provided a very visual means of the amount of work required to be carried out at the beginning of the shift. Another factor that is negatively impacting on the visual management system is the lack of a clearlydefined escalation point in relation to the control of remanufactured consumables used in the production cells. Currently calls are made to the remanufacturing cell when the allotment of consumables is used up. This is based on the current requirement that production must be kept running, regardless of the quantity of consumables used. Then, and only then, is an investigation carried out as to why the allotment has been used. Currently data is being collected but the pattern uneven flow in operations indicates that this data is not being presented in an efficient manner to drive waste from the system.

\section{Scrutiny of H2: That the introduction of standard work will support flow within the remanufacturing cell}

There has been considerable effort made up to this point to standardise the entire operation in the facility. The use of standard operating procedures and the deployment of job breakdown sheets are enabling "the one best way" to be adopted. In this respect the remanufacturing cell has carried out an extensive amount of work to standardise the remanufacture of consumable items. Currently job breakdown sheets are being used to ensure critical points in relation to the remanufacture of consumables within the cell are not missed. This has severely cut the amount of returns to the cell by promoting consistency in the standards of remanufacture between operators. This has all but eliminated quality issues and aided in reducing rework and scrap within the plant. At this point in time the reduction in variation is helping to build a matrix of standard remanufacturing times for a task enabling standard cycle times to be set. This has been done by strictly setting standards for the design of control tolerances of new consumables. Where variation between batches was once common place, the deployment of A3 problem-solving coupled with increased visibility to suppliers and the setting of safety stocks has helped to drive down the time to remanufacture.

\section{Scrutiny of H3: That the existing planning structures take little consideration of the remanufacturing cell}

Currently planning structures within the organisation in question take very little account of the remanufacturing operation. This is compounded by the current planning system i.e. weekly buckets causing visibility and pacing issues between departments. In high volume, low variety sections the weekly buckets were found to help operations to meet demand. However, if the area has complicated 
manufacturing processes incorporating many different steps in manufacture as in the grinding area within the plant, then this system does not provide enough visibility. Visual management systems are deployed (e.g. kanbans) to simplify the stocking of remanufactured parts to the production floor and reduce the amount of planning required. The only formal planning structures providing any visibility in relation to demand at this time are in relation to notification of overtime and a kitting operation which covers two cells. The pacing issues identified leading to the substitution of orders at the last minute and the lack of visibility relating to demand is hindering flow in the remanufacturing operation.

\section{Scrutiny of H4: Demand Variability in the remanufacturing cell can be managed by the introduction of the appropriate system}

Currently owing to the poor level of visibility the remanufacturing cell has in relation to daily and weekly demand a certain level of buffering is required. This negatively impacts the business and drives up inventory costs. The variability in the failure of remanufactured parts in the assembly areas of the plant must be catered for. The component areas of the plant have dramatically reduced their requirement for remanufacturing cell support by the redesign of machinery and the introduction of standard work coupled with fault-finding guides to rapidly solve issues relating to setups and the general running of machinery. This is helping to build capacity in both the remanufacturing cell and the production area it serves. Clearly as shown in the findings section there is still a high degree of variability in demand from the assembly areas. This now accounts for $80 \%$ of the workload the remanufacturing process has to process. The basis for Toyota's lean system is the use of levelled production (Womack and Jones, 2002). The problem with implementing heijunka is the fact that all parts of the operation must have clearly defined cycle times, coupled with robust planning, visual management and standard work. In a variable environment like the one in this study there would have to be substantial buffers in place to implement heijunka which would in turn drive up inventory costs. Clearly in this case conventional lean thinking will not work. There is only one system capable of dealing with this variability, the "Theory of Constraints" as originally conceived by Goldratt and Cox (1984). There is evidence to suggest that an appropriate system can be used to manage demand variability in the remanufacturing cell, however this hypothesis has not yet been proven. It would be highly beneficial to carry out a value stream mapping exercise from end to end to identify waste and give opportunities for improvement. The findings promote the understanding that conventional lean practices may not optimally address variability in this context. The Theory of Constraints approach may offer a better approach but this remains to be tested.

\section{Implications}

The purpose of this study was to investigate if even flow could be enabled in a remanufacturing cell. The study examined the application of lean systems in a remanufacturing context within an Irish based medical device manufacturer, with the end goal of providing a roadmap for improvement within the organisation. This is the first study conducted, in so far as the author is aware, in relation to the application of lean principles on the remanufacture of consumable items which aid in the assembly 
of medical devices. It must be stated that none of the consumable items are constituents of a finished device. These items are primarily used as work holding or cutting tools to aid in the manufacture of the finished guide wire. A number of findings from this research reinforce existing theories in relation to flow and remanufacturing. Chief among these being that even flow is very difficult to achieve in a remanufacturing environment due to the unpredictable rate of failure of parts, a lack of visibility in relation to production and planning procedures and unpredictable reprocessing times.

\section{Implications for the company}

The current state of the visual management systems was found to be of a very high standard. One area where the systems are deficient, however, is in their lack of interaction with the remanufacturing cell. Kucner (2008) and Sundin (2006) both found that a good visual management system supports flow within a facility, but for this to be of benefit as advocated by Kattman et al., (2012), the visual management systems must provide realtime updates of requirements to the remanufacturing cell. The use of BOC Charts is positive but the lack of an andon system within the facility which incorporates the remanufacturing cell and set trigger points for intervention, as promoted by Bicheno and Holweg (2009), is also hampering attempts to achieve consistent flow.

The use of A3 problem-solving and the introduction of standard work to the cell, as previously studied by Hunter and Black (2007), is highly beneficial. This system has ensured that critical tasks are preformed consistently without missing key parts of a task. This system has proven enormously advantageous in aiding training and reducing waste within the facility. Its introduction into the remanufacturing cell and subsequent rollout to suppliers of remanufactured parts is also proving positive. One area where it remains deficient, however, is the fact that the current standard work does not include a cycle time for completion of a task. Its introduction would help to build standardised times for remanufacture which in turn could be fed into a capacity planning system.

The current planning system of 'weekly buckets' does not provide enough finite visibility to promote flow within the operation. The only time that the remanufacturing cell gains any visibility in relation to production demands is in relation to overtime where a list is issued detailing the type and quantity of consumables required. Remanufacturing operations are traditionally hampered by a lack of visibility from both suppliers and customers. The case in question is a closed loop supply chain with a single planning function which if extended to govern the remanufacturing cell would provide a very robust flow and may ultimately reduce manufacturing costs. Whilst value stream mapping as promoted by Rother and Shook (1998) has been used selectively in other areas of the plant, its implementation to the remanufacturing cell would make waste visible and enable more robust structure of planning to be put in place. Beyond this, kanbans are deployed to simplify requirements to the cell which are replenished on a milk-run basis. In this respect Sundin (2006) advocates providing as much visibility as possible to the remanufacturing operation to promote flow, whilst Irani (2011) promotes modification of lean tools to suit the needs of the remanufacturing operation. Caputo and Pelagagge (2011) advocate the use of a 
kitting system to feed assembly operations. The remanufacturing cell currently makes limited use of this system, and it has proven to be advantageous in reducing waste.

A system that is proven to manage the variability within this environment is the Theory of Constraints, as originally advocated by Goldratt and Cox (1984) and further studied for applicability to this environment by Guide (1996) and Irani (2011). This system requires buffers of inventory to be deployed to ensure instances of stockouts do not occur.

Although this operation has well-established lean systems in place in terms of TOC, visual management systems, and standard work, it is interesting to note that these systems do not consistently nor fully extend to the remanufacturing cell, which leads to problems with sustainability. A more sustained and constant application of these tools, coupled with trigger points for escalation, would prove beneficial. Also if the production functions of this operation were to assume responsibility for the kitting and supply of consumables a more efficient service could be provided. If further gains are to be made then the planning system must afford better visibility to the remanufacturing cell.

\section{Implications for general practitioners}

This study has confirmed that lean principles do have a place in the remanufacturing and medical device industries. A broader sample of cases would be beneficial and serve to enrich the knowledge base already present on this subject. The time scale of the study was also quite short. A study over a longer time period incorporating a broader base of interviewees would prove beneficial and provide a more accurate picture of operations in the facility.

\section{Implications for future research}

As remanufacturing and lean continue to grow their strong base a further study of lean principles being applied to remanufacturing in relation to the medical device industry would be beneficial. The authors are aware that some studies have already been conducted in relation to remanufacturing of actual medical devices but is unaware at this time of a study incorporating lean remanufacturing techniques.

\section{References}

Ball, P. (2015) 'Low energy production impact on lean flow', Journal of Manufacturing Technology Management, 26 (3), pp. 412-428.

Bicheno, J. and Holweg, M. (2016) The lean toolbox. 5th edn. Buckingham: PICSIE Books.

Bicheno, J. and Holweg, M. (2009) The lean toolbox. 4th edn. Buckingham: PICSIE Books.

Caputo, A. and Pelagagge, P. (2011) 'A methodology for selecting assembly systems feeding policy', Industrial Management and Data Systems, 111 (1), pp. 84-112.

Cowton, C. (1998) 'The use of secondary data in business ethics research', Journal of Business Ethics, 17 (4), pp. 423-434. 
Creswell, J. (2007) Qualitative inquiry and research design: choosing among five approaches. 2nd edn. Thousand Oaks, CA: Sage.

DiCicco-Bloom, B. and Crabtree, B.F. (2006) 'The qualitative research interview', Medical Education, 40 (4), pp. 314-321.

Dixon, D. (2009) 'Lean in the job shop', Technical Change Associates. Available at: http://www.technicalchange.com/fandmmag-lean-thinking.html (Accessed: 5 October 2013).

Gehin, A., Zwolinski, P. and Brissaud, D. (2008) 'A tool to implement sustainable end-of-life strategies in the product development phase', Journal of Cleaner Production, 16 (5), pp. 566-576.

Goldratt, E. and Cox, J. (1984) The goal. New York: North River Press.

Guide, V. Jr. (2000) 'Production planning and control for remanufacturing: industry practice and research needs', Journal of Operations Management, 18 (4), pp. 467-483.

Guide, V. Jr. (1996) 'Scheduling using drum-buffer-rope in a remanufacturing environment', International Journal of Production Research, 34 (4), pp. 1081-1091.

Guide, V. Jr., Jayaraman, V. and Linton, J. (2003) 'Building contingency planning for closedloop supply chains with product recovery', Journal of Operations Management, 21 (3), pp. 259-279.

Harrison, A. (1995) 'Themes for promoting material flow in manufacturing systems', International Journal of Physical Distribution and Logistics Management, 25 (10), pp. 3-25.

Harrod, S. and Kanet, J. (2013) 'Applying work flow control in make-to-order job shops'. International Journal of Production Economics, 143 (1), pp. 620-626.

Hunter, S. and Black, T. (2007) 'Lean remanufacturing: a cellular case study', Journal of Advanced Manufacturing Systems, 6 (2), pp. 129-144.

Irani, S. (2011) 'Choosing what works', Industrial Engineer, 43 (8), pp. $42-47$.

Jorgensen, D. (1989) Participant observation: a methodology for human studies. Newbury Park, CA: Sage Publications.

Kattman, B., Corbin, T., Moore, L. and Walsh, L. (2012) 'Visual workplace practices positively impact business processes', Benchmarking: an International Journal, 19 (3), pp. 412-430.

Kucner, R. (2008) 'A socio-technical study of lean manufacturing deployment in the remanufacturing sector', Ph.D. Thesis, University of Michigan, US. Available at: https://deepblue.lib.umich.edu/bitstream/handle/2027.42/61694/rkucner 1.pdf?sequence=1 (Accessed: 12 October 2013).

Labach, E. J. (2010) 'Using standard work tools for process improvement', Journal of Business Case Studies, 6 (1), pp. 39-47.

Liker, J. (2004) The Toyota way. New York: McGraw-Hill.

Mähl, M. and Östlin, J. (2007) 'Lean remanufacturing - material flows at Volvo parts Flen', Master Thesis, Uppsala University, Sweden. Available at:

http://www.diva-portal.org/smash/get/diva2:131467/FULLTEXT01.pdf

(Accessed: 15 January 2014)

Martin, K. and Osterling, M. (2014) Value stream mapping: how to visualize work and align leadership for organizational transformation. [Kindle] Boston: McGraw-Hill. 
Matt, D.T. (2008) 'Template based design of lean production systems', Journal of Manufacturing Technology Management, 19, (7/8), pp. 783-797.

Nicholas, J. (1998) Competitive manufacturing management: continuous improvement, lean production and customer focused quality. Boston: McGraw-Hill.

Ohno, T. (1988) Toyota production system: beyond large-scale production. New York: Productivity Press.

Östlin, J. (2008) 'On remanufacturing systems: analysing and managing material flows and remanufacturing processes', Ph. D. Thesis, Linkoping University, Linkoping. Available at: http://liu.diva-portal.org/smash/get/diva2:18334/FULLTEXT01.pdf (Accessed: 25 January 2014).

Rother, M. and Shook, J. (1998) Learning to see: value stream mapping to add value and eliminate muda. Cambridge, MA: Lean Enterprise Institute.

Saunders, S., Lewis, P. and Thornhill, A. (2003) Research methods for business students. 3rd edn. London: Prentice Hall.

Schragenheim, E., Dettmer, H. and Patterson, J. (2009) Supply chain management at warp speed: integrating the system from end to end. 2nd edn. Boca Raton, FL: Auerbach Publications.

Spearman, M. L., Woodruff, D. L. and Hopp, W. J. (1990) 'CONWIP: a pull alternative to kanban', International Journal of Production Research, 28 (5), pp. 879-894.

Sundin, E. (2006) 'How can remanufacturing processes become leaner?', Proceedings of the 13th CIRP International Conference on Life Cycle Engineering (Leuven), pp.429-434. Available at:

https://pdfs.semanticscholar.org/14b4/a3a25478a9b479e9b943b01881399e4c5454.pdf? ga $=2.240113027 .1896040594 .1495639948-310862696.1495639948$

(Accessed: 23 January 2014).

Tezel, A., Koskela, L. and Tzortzopoulos, P. (2009) 'The functions of visual management', Proceedings of The International Research Symposium, Salford, UK. Available at: http://usir.salford.ac.uk/id/eprint/10883 (Accessed: 15 November 2013).

Womack, J.P. and Jones, D.T. (2005) Lean solutions: how companies and customers can create value and wealth together. London: Simon \& Schuster.

Womack, J.P. and Jones, D.T. (2002) Seeing the whole: mapping the extended value stream. Lean Enterprise Institute, Cambridge, MA.

Yin, R. (2003) Case study research: design and methods. 3rd edn. Thousand Oaks, CA: Sage Publications. 